\title{
WHAT CAN THE LOCATION OF BIOGAS PLANTS TELL US ABOUT AGRICULTURAL CHANGE? A CASE STUDY FROM THE CZECH REPUBLIC
}

\author{
Dan VAN DER HORST ${ }^{\mathrm{a}}$, Stanislav MARTINAT ${ }^{\mathrm{b}}$, Josef NAVRATIL ${ }^{\mathrm{c}}$, Petr DVORAK $^{\mathrm{d}}$, Petra \\ CHMIELOVA ${ }^{\mathrm{e}}$
}

\begin{abstract}
${ }^{a}$ University of Edinburgh, School of Geosciences, Drummond Library, Surgeon's Square, Drummond Street, Edinburgh EH8 9XP, UK, dan.vanderhorst@ed.ac.uk

Institute of Geonics of the Czech Academy of Sciences, Department of Environmental Geography, Drobneho 28, 60200 Brno, Czech Republic

${ }^{\mathrm{b}}$ Cardiff University, School of Geography and Planning, Glamorgan Building, King Edward VII Avenue, Cardiff, CF10 3WA, UK, martinats@cardiff.ac.uk

Institute of Geonics of the Czech Academy of Sciences, Department of Environmental Geography, Studentska 1768, 70800 Ostrava, Czech Republic

${ }^{\mathrm{c}}$ Faculty of Agriculture, University of South Bohemia in Ceske Budejovice, Studentska 13, 37005 Ceske Budejovice, Czech Republic, josefnav@gmail.com

${ }^{\mathrm{d}}$ Faculty of Science, University of Ostrava, Chittussiho 10, 71000 Ostrava, Czech Republic, petr.dvorak@osu.cz

${ }^{\mathrm{e}}$ School of Business Administration in Karvina, Silesian University in Opava, Univerzitni namesti 1934/3, 73340 Karvina, Czech Republic, E-mail: chmielova@opf.slu.cz
\end{abstract}

Cite this article: Van der Horst, D., Martinat, S., Navratil, J., Dvorak, P., Chmielova, P. (2018). What can the location of biogas plants tell us about agricultural change? A Case Study from the Czech Republic. Deturope, $10(1), 33-52$

\begin{abstract}
Facilities for generating renewable energy form important elements in the rural landscape of the Czech Republic. The distribution of these facilities is highly uneven due to various natural and socio-economic factors. In our paper, we are focusing our attention on one of the important facilities for the generation of renewable energy in the Czech Republic; anaerobic digestion (AD) plants. In 2016, more than five hundred AD plants could be found in the country with a total installed capacity of $360 \mathrm{MW}$. By means of analyses of data on location of individual AD plants, quality of soils, size of agricultural farms (in which majority of $\mathrm{AD}$ plants is incorporated) we found that agricultural AD plants in the Czech Republic tend to concentrate in areas with larger agricultural farms and also in areas with average and slightly below average conditions for agricultural activities. Core areas where agricultural AD plants are the most densely located were also identified. In these areas, large farms with AD plants tend to crowd out smaller farms. Pressure to grow maize for ADs significantly competes here with growing of other agricultural crops for food. This finding is in strong contradiction with the official national agricultural policy where support for small farms is systematically emphasized. Core areas with AD plants make a belt that mostly covers sub-mountainous central parts of the Czech Republic where traditional agricultural plants are now significantly being displaced by maize to feed AD plants.
\end{abstract}

Keywords: agricultural AD plants, natural conditions, agricultural geography, size structure of agricultural farms, Czech Republic

\section{INTRODUCTION}

The Czech Republic has seen an enormous increase in the number of anaerobic digestion (AD) plants in the period after the accession to the European Union in 2004. These AD plants are fed by farm or household wastes or energy crops and produce biogas energy that is 
transformed into electricity and heat. The current number of these stations, according to the data of the Czech biogas association (www.czba.cz), exceeds five hundred (2016) with a total installed capacity of $360 \mathrm{MW}$, whereas in 2004 there were only a few units with minimal installed capacity. The biogas plant sector annually generates about 2,000 GWh of electricity from renewable sources. The proportion of renewable energy produced from biogas in the Czech Republic to about one-quarter of the total electricity produced from renewable sources. Biogas alone already generates about $2.8 \%$ of total electricity production in the Czech Republic (2014). It is, therefore, a significant source of energy, which in addition to the electricity supplied to the transmission network also generates heat, which is currently used unfortunately only rarely, just for sporadic heating of nearby buildings and to cover the heating needs of the $\mathrm{AD}$ plant itself. This limited utilisation of the heat output makes the benefits of these facilities that could considerably support local development, quite limited (Braun, 2007). On the other hand, it is also necessary to state that the impact of the operation of biogas stations on their neighborhoods does not have to be always positive (Szymańska and Chodkowska-Miszczuk, 2011). We can mention that traffic in the proximity to AD plants is often increased due the necessity to continuously supply input material (Pantaleo et al., 2013), odour leaks from digesters may occur (Park and Novak, 2013), or an inappropriate feedstock could be used (Marcato et al., 2009), which undoubtedly reduces the environmental benefits of produced renewable energy and complicates the lives of local population (ChodkowskaMiszczuk et al., 2017). The problem is therefore in emerging resistance of a part of the local population against the operation of AD plants (Martinát et al., 2013), the perception of biogas as a source of renewable energy (Doci and Gotchev, 2016) or in the general opposition to the localization of energy plants (Frantál et al, 2016).

There is no doubt that $\mathrm{AD}$ plants are distributed unevenly within the Czech Republic. Some AD plants process sludge from sewage treatment plants, others process waste from food production. These types of $\mathrm{AD}$ are typically located in suburban locations. However, the largest number of stations (more than $300 \mathrm{AD}$ plants) are agricultural $\mathrm{AD}$ plants located in the countryside. This type of AD plants should be mostly focused on the energy processing of agricultural wastes, which would otherwise have been left unused. Nevertheless, in the conditions of the Czech Republic, these agricultural AD plants primarily run on intentionally grown green maize. Our earlier studies suggest (Martinát et al., 2013, 2016), that AD plants are associated with a changing structure of sowing areas of agricultural crops in the Czech Republic as a result of the massive use of intentionally grown green maize (currently covering about 230,000 hectares). At the same time there has been a significant reduction of the number of livestock (as a result of cheap imports), which used to consume green maize. A 
third observation is the high installed capacity of the biogas stations operating in the Czech Republic (typically 0.7-0.8 MW). For comparison, in neighbouring Germany, where we find about eight thousands of such devices, their average size is significantly smaller and their primary focus on energy processing of agricultural wastes and household wastes is also different. Similar observation can be made in the UK (Styles et al., 2016) or in Poland where $\mathrm{AD}$ investments are usually separated from agricultural companies (Budzianowski, 2012, Chodkowska-Miszczuk and Szymańska, 2013). It can be therefore assumed that with such a large installed capacity of the individual stations, there is pressure to change the use of sowing areas near the biogas stations, in order to supply sufficient feedstock to keep the plant running. Connected environmental consequences as for example a higher level of soil erosion (Centeri et al., 2015) while growing maize are obvious. Thus, the aim of this paper is to explore the relationship between the presence of $\mathrm{AD}$ plants, farm types and agricultural conditions in the Czech Republic.

It is clear that agricultural biogas stations have a significant potential to influence the quality of life and local development in positive and negative terms (Darnhofer 2005, Plieninger et al., 2006, Martinat and Turečková, 2016). The massive subsidy support of the Government of the Czech Republic for renewable energy, was a consequence of a commitment towards to the European Union of producing $13.5 \%$ electricity from renewable sources by 2020 (National Action Plan for Development Renewable Energy, 2010). AD plants have become a significant alternative income for farmers in times when their revenues from traditional agricultural activities are declining. Despite original policy ambitions, it is less clear to what extent $\mathrm{AD}$ plants have been an effective tool for limiting the impacts of climate change or for local development support (Doležalová et al., 2009, 2014a, 2014b, Ženka et al., 2016 or Duzi et al., 2017). It is therefore important to research also the attitudes and views of farmers on this significant change in the use of agricultural land (Frantál and Prousek 2016, Silva and Delicado, 2017). This change is related to a pan-European approach to the use of renewable energy resources and the limitation of the use of traditional resources of energy. The theoretical conceptualization of this problem for example can be found in the concept of energy transition (Van der Horst, 2014, Frantál et al., 2014 or Bridge et al., 2016).

The aim of this paper is to explore the relationship between the presence of AD plants, farm types and agricultural conditions in the Czech Republic.

\section{THEORETICAL BACKGROUND}

It is clear that the size of agricultural farms significantly influences the decision making of their managements on how to develop economic strategies of particular farms. One of the 
more traditional simple answers to this problem could be found in theory on economies of scale that can be traced back to the classic economists of the $18^{\text {th }}$ century (Krugman, 1980). Many authors have explored this issue, e.g. agriculture in Germany (Fernandez-Cornejo et al., 1992), the Corn Belt in the USA (Paul et al., 2004) or agriculture in the Central European countries (Gorton and Davidova, 2004). Fewer authors have devoted their endeavour to the theoretical implications that are linked to economies of scale in agriculture (like e.g. Duffy, 2009 or more recently de Roest et al., 2017). De Roest et al. (2017) in their study declare that the size of farms really matters when discussing their necessary diversification.

The size of $\mathrm{AD}$ plants is a key factor affecting their economic profitability (Skovsgaard and Jacobsen, 2017). However it is not clear what size of AD plant should be the most beneficial for the host municipality. We know from previous researches that operators of AD plants (usually owners of agricultural farms in the case of the Czech Republic) prefer bigger sized AD plants due to profitability (Martinat et al., 2013). But such decisions are accompanied by much more complicated logistics; large amounts of input material have to be continuously transported to the $\mathrm{AD}$ and thus stored) or environmental problems (odour, cleaning of roads etc.). It has to be stressed that large farms (around thousand hectares in the Czech Republic), also have better access to money for investments so their decision making about future activities is more flexible.

As for the hosting municipality where $\mathrm{AD}$ plant is located, other factors are important. First of all, it is the suitable location of the AD within a municipality that seems to be of crucial importance (Martinat and Tureckova, 2016). The local population strongly appreciate if the benefits that are generated from local AD plant are shared with them (Soland et al., 2013), e.g. in the form of heat supplies at reasonable prices or in the form of funding for the local community (Klagge and Brocke, 2012). AD plant can be also treated as attraction for tourists that might be beneficial for local entrepreneurs (Upreti and Van der Horst, 2004, Zoellner et al., 2008, Navrátil et al., 2015).

Another concept that offers different perspective while thinking about consequences of biogas energy and local development is a concept of circular economy. Usage of local agricultural and households waste for energy processing that is consumed locally seems to be the most environmentally beneficial way to deal with this issue. A concept is widely discussed for example by Paul et al. (2017) or Pan et al. (2015) who warn that waste that is processed in $\mathrm{AD}$ plants should be rather reworded to resource that enables closing the local consumption loop to beneficial circle. 


\section{METHODOLOGY AND DATA}

In order to study the specifics of agricultural structures in areas with the intensive operation of agricultural AD plants, we used the data of the Czech Statistical Office related to farm numbers in size categories according to the size of farmed agricultural areas from 2002 and 2010. The first named year determines the period before the beginning of the dynamic growth of the number of AD plants, i.e. prior to the country's accession to the European Union, which meant the start of the supports for renewable energy. The second year mentioned is the last year for which these data were published in a comparable time series. This period is characterized by an intensive transformation of the structures and extent of agriculture in the Czech Republic due to the opening of the internal market for agricultural imports.

Due to the unavailability of data on the state and development of agricultural activities in the lower territorial units of the Czech Republic (municipalities or municipalities with extended competences), the data on the district level was used for the analyses. In the first step, were grouped data on agricultural AD plants (location, installed capacities) into 77 districts. In this way we identified districts of the Czech Republic, where we suppose hypothetically the greatest impact of these stations on the changes of local agricultural structures. For these calculations, the data related to AD plants originating from the Energy Regulatory Office of the Czech Republic (www.eru.cz) for 2012 (i.e. 243 units with a total installed capacity of 171.4 MW) was used. We were interested in the number of agricultural $\mathrm{AD}$ plants and their total installed capacity in individual districts. We suppose that the higher the total installed capacity of agricultural AD plants in the district, the higher the pressure on the changes in agricultural structures should be evident. In order to refine the model and therefore to more accurately identify the area surveyed, the total installed capacity was weighed by the size of the agricultural land in the individual districts. The expected intensity of installed capacity of agricultural AD plants was calculated for the individual districts of the Czech Republic (see Tab. 1 and Fig. 1). These fourteen districts account for approximately one-fifth of the area of the Czech Republic (20.6\%), where are distributed $16.1 \%$ of agricultural land and $23.3 \%$ of arable land on the basis of the results of the last available agricultural census (Agrocensus, 2010). The total installed capacity of the agricultural AD plants in the area is $44.6 \%$ of the national total. In terms of numbers, it is $40.7 \%$ (99 stations) of the national total in 2012. 
Table 1 Delimitation of areas with significant operation of agricultural AD plants (districts of the Czech Republic)

\begin{tabular}{|c|c|c|c|}
\hline $\begin{array}{l}\text { order of districts with the } \\
\text { highest installed capacity } \\
\text { of AD plants per hectare of } \\
\text { agricultural land }\end{array}$ & $\begin{array}{lr}\text { installed } & \text { capacity } \\
\text { converted } & \text { to } \\
\text { agricultural } & \text { land } \\
(M W / h a) & \\
\end{array}$ & $\begin{array}{l}\text { order of districts with the } \\
\text { highest installed capacity } \\
\text { of AD plants per hectare of } \\
\text { agricultural land }\end{array}$ & $\begin{array}{lr}\text { installed } & \text { capacity } \\
\text { converted } & \text { to } \\
\text { agricultural } & \text { land } \\
(\mathrm{MW} / \mathrm{ha}) & \\
\end{array}$ \\
\hline \multicolumn{2}{|c|}{ group B1 } & \multicolumn{2}{|c|}{ group B2 } \\
\hline Karviná (1) & 0.165 & Nový Jičín (8) & 0.095 \\
\hline Domažlice (2) & 0.127 & Náchod (9) & 0.092 \\
\hline Svitavy (3) & 0.127 & Třebíč (10) & 0.091 \\
\hline Jihlava (4) & 0.114 & Příbram (11) & 0.083 \\
\hline Havlíčkův Brod (5) & 0.104 & Jičín (12) & 0.075 \\
\hline Ústi nad Orlicí (6) & 0.102 & Pelhřimov (13) & 0.074 \\
\hline Rychnov nad Kněžnou (7) & 0.096 & České Budějovice (14) & 0.074 \\
\hline
\end{tabular}

Source: Energy Regulatory Office of the Czech Republic (www.eru.cz), Agrocenzus 2010, own calculations.

Figure 1 Groups of districts of the Czech Republic (B1, B2) with the most significant operation of agricultural AD plants

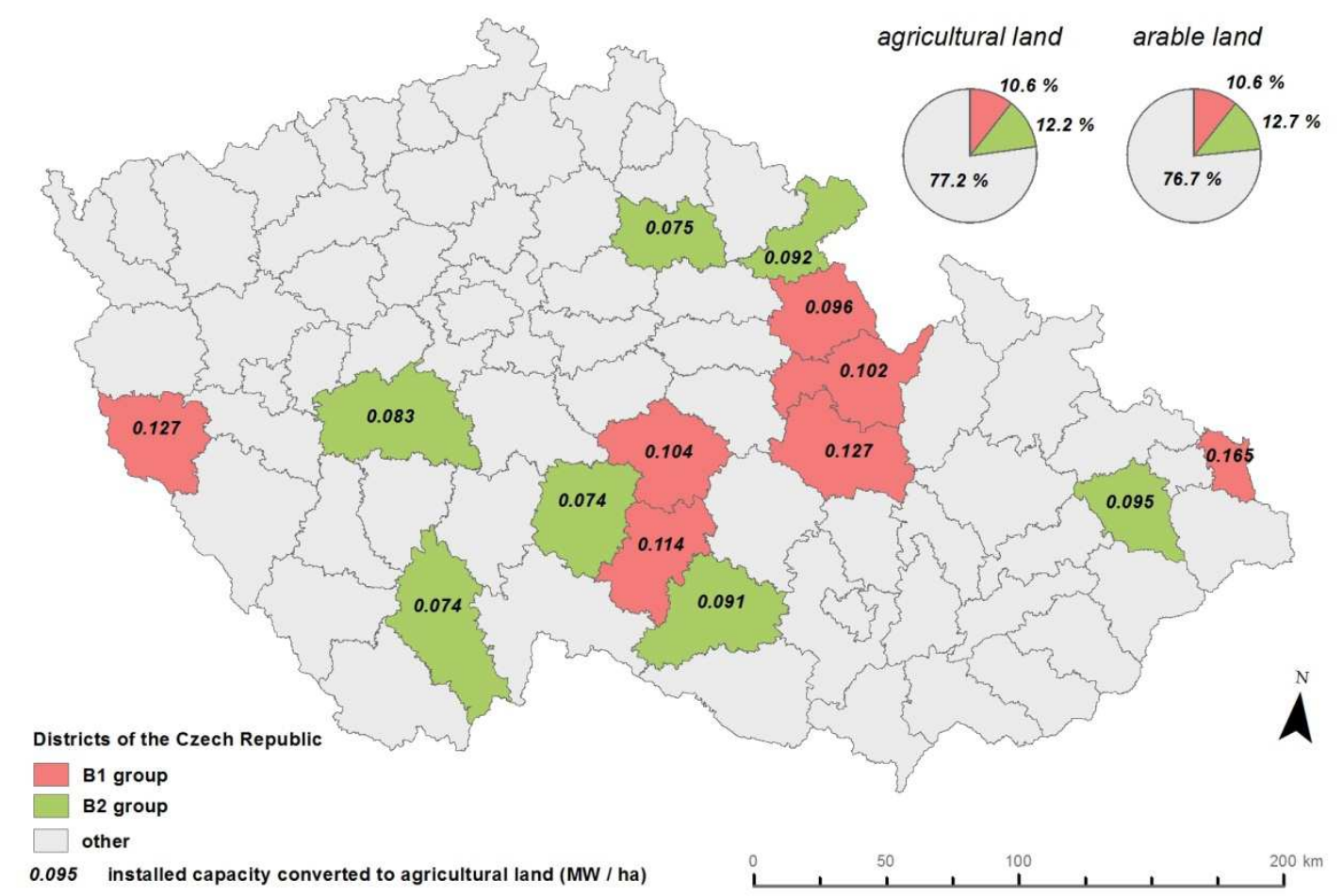

Source of data: Energy Regulatory Office of the Czech Republic (www.eru.cz), Agrocenzus 2010, author's processing.

We divided the 14 districts mentioned above into 2 groups of districts in which we assume a different intensity of the impact of agricultural biogas stations on local agricultural structures. Based on the intensity of the installed capacity converted to the area of agricultural land in the district, we created groups B1 (with significant intensity) and groups B2 (with less significant intensity). In the analyses, we compared the groups of districts B1, B2 and B (i.e. B = B1 + B2) with the rest of the Czech Republic ( $\left.\sum \mathrm{CZ}\right)$. Individual groups of districts cover a quarter 
(B1) and one fifth (B2) of the installed capacity of agricultural AD plants in the Czech Republic. Further, the area outside the area B ( $\Sigma$ OTHER) was also considered (see Tab. 2).

It is evident that, in the context of ongoing structural changes, far more factors are involved in agriculture than just the installation and operation of agricultural biogas stations. At the forefront of these factors, which significantly affect the deployment and transformation of agricultural activities, are the natural conditions with which agriculture is closely linked. It is therefore relatively complicated to decide which changes in agricultural structures can be identified in the territory as a consequence of primary or secondary factors and whether the primary driving force of change were natural conditions or other factors, such as agricultural biogas stations.

Table 2 Basic characteristics of groups of districts of the Czech Republic based on intensity of operation of agricultural $\mathrm{AD}$ plants

\begin{tabular}{|l|c|c|c|c|c|c|}
\hline & \multicolumn{2}{|c|}{ total area } & \multicolumn{2}{c|}{ agricultural land } & \multicolumn{2}{c|}{ arable land } \\
\hline Groups & abs. (ha) & rel. (\%) & abs. (ha) & rel. (\%) & abs. (ha) & rel. (\%) \\
\hline B1 & 757,169 & 9.6 & 370,818 & 10.6 & 268,082 & 10.6 \\
\hline B2 & 870,399 & 11.0 & 423,325 & 12.2 & 318,698 & 12.7 \\
\hline E B & $1,627,568$ & 20.6 & 794,143 & 22.8 & 586,780 & 23.3 \\
\hline E OTHER & $6,259,044$ & 79.4 & $2,689,355$ & 77.2 & $1,927,068$ & 76.7 \\
\hline E CZ & $7,886,612$ & 100.0 & $3,483,498$ & 100.0 & $2,513,848$ & 100.0 \\
\hline
\end{tabular}

Source: Source: Energy Regulatory Office of the Czech Republic (www.eru.cz), Agrocenzus 2010, own calculations.

The individual districts of the Czech Republic were grouped according to the natural conditions for farming, which serve to uncover the trends caused regional differentiation of natural conditions. The natural conditions are represented in this case by the average price of agricultural land, which was calculated for each of the districts as the arithmetic average of agricultural land prices for the individual cadastral areas of the district. Agricultural land prices that we used can be termed as administrative ones (not market prices), which were calculated only on the basis of local natural conditions (according to the soil ecological units), socio-economic factors were not taken into account. The database of so-called official farm land prices is available as an annexe to the Decree No. 463/2002 Coll., which establishes a list of cadastral territories with assigned average administrative basic prices of agricultural parcels in the Czech Republic (Mze, 2002). The selected methodological approach slightly diminishes the existing inter-district differences of the natural and agricultural conditions, but for our purposes, the choice of this indicator seems not to be a problem. The districts of the Czech Republic (77 units) were at first sorted according to the average price of agricultural land in the district and further grouped into 7 groups (see Tab. 3 and Fig. 2) which are representing 
different natural conditions for agricultural management. The basic size characteristics of each from groups of districts are illustrated in Tab. 4. It is evident that the individual groups of districts have a different "agricultural" size due to the unbalanced natural conditions in the Czech Republic. If we try to generalize the natural conditions found in the groups of districts, then one-sixth of the agricultural land is situated in sub-mountainous areas and almost onethird of it is in mountainous conditions. By contrast, more than a quarter of farmland is distributed in the most fertile areas. Taking into consideration that the average official price of agricultural land is $4.73 \mathrm{CZK} / \mathrm{m}^{2}\left(0.18 \mathrm{Euro} / \mathrm{m}^{2}\right)$ according to the authors' calculations in the Czech Republic (this price differs from the information of the Czech Ministry of Agriculture that the average land price in the Czech Republic is $5.24 \mathrm{CZK} / \mathrm{m}^{2}$, however for the other calculations, this difference is insignificant), then in the below-average conditions almost twothirds of the agricultural land could be found.

Table 3 Groups of districts of the Czech Republic according to natural conditions for agriculture

\begin{tabular}{|c|c|}
\hline $\begin{array}{l}\leq 2.99 \mathrm{CZK}^{\mathrm{i}} / \mathrm{m}^{2} \\
\left(\leq 0.11 \text { Euro } / \mathrm{m}^{2}\right)\end{array}$ & $\begin{array}{c}\text { Jablonec nad Nisou, Prachatice, Český Krumlov, Klatovy, Sokolov, Bruntál, } \\
\text { Jihlava, Jeseník, Vsetín, Žd'ár nad Sázavou, Semily Karlovy Vary, Tachov, } \\
\text { Trutnov }\end{array}$ \\
\hline $\begin{array}{l}3-3.99 \mathrm{CZK} / \mathrm{m}^{2} \\
(0.11-0.15 \text { Euro / } \\
\left.\mathrm{m}^{2}\right)\end{array}$ & $\begin{array}{l}\text { Cheb, Ústi nad Labem, Domažlice, Děčín, Jindřichův Hrádek, Pelhřimov, } \\
\text { Frýdek-Místek, Př́bram, Strakonice, Sumperk, Liberec, Chomutov, Rychnov nad } \\
\text { Kněžnou, Rokycany, Havlíčkův Brod, Plzeň-jih, Písek, České Budějovice, Plzeň- } \\
\text { sever, Zlín, Benešov, Tábor }\end{array}$ \\
\hline $\begin{array}{l}4-4.99 \mathrm{CZK} / \mathrm{m}^{2} \\
(0.15-0.19 \text { Euro / } \\
\left.\mathrm{m}^{2}\right)\end{array}$ & $\begin{array}{c}\text { Beroun, Blansko, Novy Jičín, Ústi nad Orlicí, Náchod, Teplice, Rakovník, } \\
\text { Svitavy, Most, Třebíč, Česká Lípa }\end{array}$ \\
\hline $\begin{array}{l}5-5.99 \mathrm{CZK} / \mathrm{m}^{2} \\
(0.19-.023 \text { Euro / } \\
\left.\mathrm{m}^{2}\right)\end{array}$ & Plzeň-město, Karviná, Ostrava, Opava, Chrudim, Louny \\
\hline $\begin{array}{l}6-6.99 \mathrm{CZK} / \mathrm{m}^{2} \\
(0.23-0.27 \text { Euro / } \\
\left.\mathrm{m}^{2}\right)\end{array}$ & Litoměřice, Praha-západ, Kutna Hora, Pardubice, Uherské Hradiště \\
\hline $\begin{array}{l}7-7.99 \mathrm{CZK} / \mathrm{m}^{2} \\
(0.27-0.31 \text { Euro / } \\
\left.\mathrm{m}^{2}\right)\end{array}$ & $\begin{array}{c}\text { Praha, Kladno, Praha-východ, Mělník, Brno-město, Brno-venkov, Přerov, } \\
\text { Hodonín, Jičín }\end{array}$ \\
\hline $\begin{array}{l}\geq 8 \mathrm{CZK} / \mathrm{m}^{2} \\
(\geq 0.31 \quad \text { Euro } / \\
\left.\mathrm{m}^{2}\right)\end{array}$ & $\begin{array}{l}\text { Prostějov, Znojmo, Olomouc, Vyškov, Břeclav Mlada Boleslav, Kroměříž, } \\
\text { Nymburk, Kolín, Hradec Králové }\end{array}$ \\
\hline
\end{tabular}


Figure 2 Districts of the Czech Republic according to natural conditions for agriculture based on the administrative average prices of agricultural land



Source: Annex to the Decree No. 463/2002 Coll. (prices of agricultural lands).

Table 4 Groups of districts of the Czech Republic according to natural conditions for agriculture (according to administrative average value of agricultural land)

\begin{tabular}{|l|c|c|c|c|c|c|}
\hline & \multicolumn{2}{|c|}{ total area } & \multicolumn{2}{c|}{ agricultural land } & \multicolumn{2}{c|}{ arable land } \\
\hline $\begin{array}{c}\text { price of agricultural } \\
\text { land }\end{array}$ & abs. (ha) & rel. (\%) & abs. (ha) & rel. (\%) & abs. (ha) & rel. (\%) \\
\hline $\begin{array}{l}\leq 2.99 \mathrm{CZK}^{\mathrm{i}} / \mathrm{m}^{2} \\
\left(\leq 0.11 \mathrm{Euro} / \mathrm{m}^{2}\right)\end{array}$ & $1,700,609$ & 21.6 & 575,475 & 16.5 & 252,521 & 10.0 \\
\hline $\begin{array}{l}3-3.99 \mathrm{CZK} / \mathrm{m}^{2} \\
\left(0.11-0.15 \mathrm{Euro} / \mathrm{m}^{2}\right)\end{array}$ & $2,558,452$ & 32.4 & $1,075,235$ & 30.9 & 700,368 & 27.9 \\
\hline $\begin{array}{l}4-4.99 \mathrm{CZK} / \mathrm{m}^{2} \\
\left(0.15-0.19 \mathrm{Euro} / \mathrm{m}^{2}\right)\end{array}$ & $1,027,204$ & 13.0 & 459,390 & 13.2 & 343,799 & 13.7 \\
\hline $\begin{array}{l}5-5.99 \mathrm{CZK} / \mathrm{m}^{2} \\
\left(0.19-.023 \mathrm{Euro} / \mathrm{m}^{2}\right)\end{array}$ & 417,237 & 5.3 & 208,417 & 6.0 & 172,516 & 6.9 \\
\hline $\begin{array}{l}6-6.99 \mathrm{CZK} / \mathrm{m}^{2} \\
\left(0.23-0.27 \mathrm{Euro} / \mathrm{m}^{2}\right)\end{array}$ & 440,113 & 5.6 & 225,690 & 6.5 & 195,022 & 7.8 \\
\hline $\begin{array}{l}7-7.99 \mathrm{CZK} / \mathrm{m}^{2} \\
\left(0.27-0.31 \mathrm{Euro} / \mathrm{m}^{2}\right)\end{array}$ & 723,206 & 9.2 & 356,211 & 10.2 & 319,825 & 12.7 \\
\hline $\begin{array}{l}\geq 8 \mathrm{CZK} / \mathrm{m}^{2} \\
\left(\geq 0.31 \text { Euro } / \mathrm{m}^{2}\right)\end{array}$ & $1,019,791$ & 1.9 & 583,080 & 16.7 & 529,797 & 21.1 \\
\hline$\sum \mathrm{CZ}$ & $7,886,612$ & 100.0 & $3,483,498$ & 100.0 & $2,513,848$ & 100.0 \\
\hline
\end{tabular}

Source: Czech Office of Cadastre and Surveying (www.cuzk.cz), Agrocenzus 2010, Annex to Decree No. 463/2002 Coll. (prices of agricultural lands).

${ }^{i}$ As administrative prices (not market prices) of agricultural lands are used for our calculations, natural conditions for agriculture can be simply ranked from the worst (the lowest prices) to the best (the highest prices).

\section{RESULTS}

\section{Size categories of agricultural farms}

A nationwide overview of the size of the farms in four size categories (less than 9.99 ha, 10- 
44.9 ha, 50-99.9 ha and more than 100 hectares of agricultural land) is provided in Tab. 5. In 2010 two thirds of farms in the Czech Republic were below the size of 9.99 hectares of agricultural land, a one fifth was in the range of 10-49.99 hectares and only about a tenth of farms were larger than 100 hectares. This deployment recorded interesting shifts over the studied period. It is necessary to emphasize that the total number of farms in the period 20022010 decreased by $17 \%$ to 44.5 thousand, corresponding to the drop in the number of the smallest farms (up to 9.99 hectares), which decreased by almost one fifth. The reduction of the number has occurred also in the case of farms with an area of 10-49.99 hectares, by about $8 \%$. Clearly, there are shifts in favour of larger farms, especially in the case of farms with an area of 50-99.99 hectares (up to almost one-third), a lower intensity of growth is evident for hundred-hectare farms and larger farms (about 9\%). It can be said that there is a dynamic concentration of farmed agricultural land in larger farms with 50 hectares or more at the expense of the smallest farms whose economic activities are economically less efficient. Despite this fact, the average size of the farm is gradually decreasing.

Table 5 Numbers of farms in the Czech Republic in 2002 and 2010 in the size categories of agricultural land

\begin{tabular}{|c|c|c|c|c|c|c|}
\hline \multirow{2}{*}{ ha } & \multicolumn{2}{|c|}{2002} & \multicolumn{2}{c|}{2010} & $\begin{array}{c}\text { index of } \\
\text { change }\end{array}$ & $\begin{array}{c}\text { the difference } \\
\text { (2010-2002) }\end{array}$ \\
\cline { 2 - 7 } & $\begin{array}{c}\text { number } \\
\text { offarms }\end{array}$ & $\begin{array}{c}\text { the share of farms } \\
\text { in the total number } \\
\text { offarms in the } \\
\text { Czech Republic } \%\end{array}$ & $\begin{array}{c}\text { number of } \\
\text { farms }\end{array}$ & $\begin{array}{c}\text { the share of } \\
\text { farms in the total } \\
\text { number of farms } \\
\text { in the Czech } \\
\text { Republic\% } \%\end{array}$ & $\begin{array}{c}\text { year 2002 } \\
=100\end{array}$ & $\begin{array}{c}\text { the share of } \\
\text { farms in the total } \\
\text { number of farms } \\
\text { in the Czech } \\
\text { Republic }\end{array}$ \\
\hline$\leq 9.99$ & 38,162 & 71.1 & 30,840 & 66.4 & 80.8 & -4.7 \\
\hline $10-49.99$ & 9,717 & 18.1 & 8,957 & 19.3 & 92.2 & +1.2 \\
\hline $50-99.99$ & 1,759 & 3.3 & 2,310 & 5.0 & 131.3 & +1.7 \\
\hline$\geq 100$ & 4,029 & 7.5 & 4,370 & 9.4 & 108.5 & +1.9 \\
\hline$\sum \mathrm{CZ}$ & 53,667 & 100.0 & 46,447 & 100.0 & 86.6 & \\
\hline
\end{tabular}

Source: Czech Statistical Office, own calculations.

For a more detailed analysis of the size of agricultural farms with regard to natural conditions and the occurrence of $\mathrm{AD}$ plants, we will deal with the individual size categories of agricultural holdings separately. First, we will focus on the smallest farms with an area of 9.99 hectares of agricultural land. As mentioned above, these farms account for two-thirds of the number of farms in the Czech Republic and are the most numerous category. These are in particular small farmers who have restituted their land and, in particular, family farms managing limited areas. It is understandable that in this category of farms there is the most significant fluctuation of the number of farms due to the inclusion of very small, economically hardly sustainable farms, which very often emerge as well as disappear. However, let us now take a look at the structure of this category of the smallest agricultural holdings. 


\section{Farms with less than 9.99 hectares of agricultural land}

As can be seen from Tab. 6, in terms of changing conditions for agricultural management, there is a certain differentiation in both the time horizons observed. While in the case of the mountain, foothill areas and areas with average and slightly above average natural conditions, the share of these smallest farms in their total number is in very balanced proportions (61$63 \%$ ); in the case of the most lucrative areas, this is a higher proportion (about $75 \%$ ). A similar distribution is also visible for the 2000 starting year, so we can state a certain higher degree of stability for the smallest farms in the most fertile areas. This hypothesis is supported by a much more intensive decline of the smallest farms in the examined intervals in mountain and sub-mountain areas than in more fertile areas. The only category where the number of farms has stagnated is precisely these fertile areas. It can be said that from the point of view of the internal structure of these small farms, farms move from areas less suited to farming to more suitable areas. This assumption is related to the low efficiency of farming these small farms in mountain and foothill areas.

Table 6 Distribution of farms in size 9.99 and less hectares in the Czech Republic in 2002 and 2010 according to natural conditions for agriculture

\begin{tabular}{|l|c|c|c|}
\hline price of agricultural land & $\begin{array}{c}\text { number of farms } \\
(2002)\end{array}$ & $\begin{array}{c}\text { number of farms } \\
(2010)\end{array}$ & $\begin{array}{c}\text { year } 2002= \\
100\end{array}$ \\
\hline$\leq 2.99 \mathrm{CZK} / \mathrm{m}^{2}\left(\leq 0.11\right.$ Euro $\left./ \mathrm{m}^{2}\right)$ & 6,955 & 5,298 & 76.2 \\
\hline $3-3.99 \mathrm{CZK} / \mathrm{m}^{2}\left(0.11-0.15\right.$ Euro $\left./ \mathrm{m}^{2}\right)$ & 9,871 & 7,700 & 78.0 \\
\hline $4-4.99 \mathrm{CZK} / \mathrm{m}^{2}\left(0.15-0.19\right.$ Euro $\left./ \mathrm{m}^{2}\right)$ & 4,621 & 3,298 & 71.4 \\
\hline $5-5.99 \mathrm{CZK} / \mathrm{m}^{2}\left(0.19-.023\right.$ Euro $\left./ \mathrm{m}^{2}\right)$ & 1,651 & 1,514 & 91.7 \\
\hline $6-6.99 \mathrm{CZK} / \mathrm{m}^{2}\left(0.23-0.27\right.$ Euro $\left./ \mathrm{m}^{2}\right)$ & 2,024 & 1,570 & 77.6 \\
\hline $7-7.99 \mathrm{CZK} / \mathrm{m}^{2}\left(0.27-0.31\right.$ Euro $\left./ \mathrm{m}^{2}\right)$ & 4,878 & 4,915 & 100.8 \\
\hline$\geq 8 \mathrm{CZK} / \mathrm{m}^{2}\left(\geq 0.31\right.$ Euro $\left./ \mathrm{m}^{2}\right)$ & 8,162 & 6,545 & 80.2 \\
\hline$\sum \mathrm{CZ}$ & 38,162 & 30,840 & 80.8 \\
\hline
\end{tabular}

Source: Czech Statistical Office, own calculations.

${ }^{\mathrm{i}}$ As administrative prices (not market prices) of agricultural lands are used for our calculations, natural conditions for agriculture can be simply ranked from the worst (the lowest prices) to the best (the highest prices).

Table 7 Distribution of farms in size 9.99 land and less in the Czech Republic in 2002 and 2010 according to intensity of operation of agricultural AD plants

\begin{tabular}{|l|c|c|c|}
\hline \multicolumn{1}{|c|}{ groups } & number of farms (2002) & number offarms (2010) & year 2002 $=100$ \\
\hline B1 & 3,729 & 2,489 & 66.7 \\
\hline B2 & 3,405 & 2,674 & 78.5 \\
\hline$\sum$ B & 7,134 & 5,163 & 72.4 \\
\hline$\sum$ OTHER & 31,028 & 25,677 & 82.8 \\
\hline$\sum$ CZ TOTAL & 38,162 & 30,840 & 80.8 \\
\hline
\end{tabular}

Source: Czech Statistical Office, own calculations.

In areas with very intensive operation of agricultural biogas stations (area B1) we find a relatively lower representation of the smallest farms (less than 9.99 hectares), and particularly in area B1 there are noticeable very strong drops in their numbers (up to one third), which hasn't occurred in other types of investigated areas (see Tab. 7). The number of these smallest 
farms is declining very quickly as a results of crowding out by large farms with AD plant that expand their growing of maize as much as possible.

\section{Farms with 10-49.99 hectares of agricultural land}

In the case of farms with an area of 10-49.99 hectares, which account for roughly one-fifth of farms in the Czech Republic, interesting spatial specifics can also be identified. A characteristic feature of these farms is their changing share in various natural conditions. Thus, while we see above $22 \%$ (above the national average) in the case of the mountain, foothill and agricultural average areas, the share of this type of farms is declining to $12 \%$ for the most fertile areas. While the share of these farms increases in the total number of the mountain, foothill and average areas in the meantime, in fertile areas, this type is rather stagnant and slightly declining (Tab. 8).

If we look at the specifics of areas with agricultural biogas stations, we see an increased occurrence of these farms (an area of 10-49.99 hectares - see Tab. 9). In the case of area B2, these farms account for even a quarter of the total, which is exceptional in the sample, with B1 showing significant increases in the share of farms (by almost 3\%, which is more than in the case of mountain areas). In terms of the number of farms in the period under review, declines in the number of farms with a size of 10-49.99 hectares are relatively strong (decrease by 13\%), the increasing relative importance of these farms is primarily due to the abovementioned decline in the smallest farms.

Table 8 Distribution of farms in size category from 10 to 49.99 hectares in the Czech Republic in 2002 and 2010 according to natural conditions for agriculture

\begin{tabular}{|l|c|c|c|}
\hline \multicolumn{1}{|c|}{ price of agricultural land } & $\begin{array}{c}\text { number of farms } \\
(2002)\end{array}$ & $\begin{array}{c}\text { number of farms } \\
(2010)\end{array}$ & $\begin{array}{c}\text { year } 2002= \\
100\end{array}$ \\
\hline$\leq 2.99 \mathrm{CZK}^{1} / \mathrm{m}^{2}\left(\leq 0.11\right.$ Euro $\left./ \mathrm{m}^{2}\right)$ & 1,986 & 1,901 & 95.7 \\
\hline $3-3.99 \mathrm{CZK} / \mathrm{m}^{2}\left(0.11-0.15\right.$ Euro $\left./ \mathrm{m}^{2}\right)$ & 3,039 & 2,830 & 93.1 \\
\hline $4-4.99 \mathrm{CZK} / \mathrm{m}^{2}\left(0.15-0.19\right.$ Euro $\left./ \mathrm{m}^{2}\right)$ & 1,485 & 1,245 & 83.8 \\
\hline $5-5.99 \mathrm{CZK} / \mathrm{m}^{2}\left(0.19-.023\right.$ Euro $\left./ \mathrm{m}^{2}\right)$ & 486 & 524 & 107.8 \\
\hline $6-6.99 \mathrm{CZK} / \mathrm{m}^{2}\left(0.23-0.27\right.$ Euro $\left./ \mathrm{m}^{2}\right)$ & 537 & 429 & 101.9 \\
\hline $7-7.99 \mathrm{CZK} / \mathrm{m}^{2}\left(0.27-0.31\right.$ Euro $\left./ \mathrm{m}^{2}\right)$ & 932 & 950 & 86.1 \\
\hline$\geq 8 \mathrm{CZK} / \mathrm{m}^{2}\left(\geq 0.31\right.$ Euro $\left./ \mathrm{m}^{2}\right)$ & 1,252 & 1,078 & 92.2 \\
\hline$\sum \mathrm{CZ} \mathrm{TOTAL}$ & 9,717 & 8,957 & \\
\hline
\end{tabular}

Source: Czech Statistical Office, own calculations.

${ }^{\mathrm{i}}$ As administrative prices (not market prices) of agricultural lands are used for our calculations, natural conditions for agriculture can be simply ranked from the worst (the lowest prices) to the best (the highest prices).

Table 9 Distribution of farms in size category from 10 to 49.99 hectares in the Czech Republic in 2002 and 2010 according to intensity of operation of agricultural AD plants

\begin{tabular}{|l|c|c|c|}
\hline \multicolumn{1}{|c|}{ groups } & number of farms (2002) & number of farms (2010) & year 2002 $=100$ \\
\hline B1 & 993 & 866 & 87.2 \\
\hline B2 & 1,332 & 1,155 & 86.7 \\
\hline$\sum$ B & 2,325 & 2,021 & 86.9 \\
\hline$\sum$ OTHER & 7,392 & 6,936 & 93.8 \\
\hline$\sum$ CZ TOTAL & 9,717 & 8,957 & 92.2 \\
\hline
\end{tabular}

Source: Czech Statistical Office, own calculations. 


\section{Farms with 50-99.99 hectares of agricultural land}

Farms with an area of 50-99.99 hectares, which can be considered to be an average farm in terms of their size, account for $5 \%$ of the total number of farms in the Czech Republic in 2010. There is also a link between the changes in the share of this type of farms and the changing natural conditions. While the share of farms with an area of 50-99.99 hectares exceeded $5.5 \%$ in mountain and foothill areas in 2010, this share fell to $3.3 \%$ in the most fertile areas with improved natural conditions (Tab. 10). This change can be related to a higher concentration of farms in larger, more economically efficient units in mountain and sub-mountain areas, while in the most fertile areas the pressure on mergers isn't so large due to the high quality of agricultural land and hence the high efficiency of farming. This assumption explains both the increase in percentage points for the share of these farms as a whole, as well as the very high increases in the absolute number of farms in mountain areas (almost 60\%). When talking about the internal structure of the distribution with farms with an area of 50-99.99 hectares, there are not more than half of them in the mountain and foothill areas in the Czech Republic.

It appears that farms with an area of 50-99.99 hectares, not only in mountain and submountain areas but also in areas with intensively-run agricultural biogas stations seem to play a very strong role. The share of the number of farms from the total number of farms is relatively higher compared to natural conditions (up by 7.3\% in B2 category - Tab. 11). The share of these farms, calculated for the Czech Republic (5.0\%), is lower than the figure for the total category B (6.6\%). Here, too, attention is given to the growing importance of this category within each size range of farms, which is stronger than for mountain and foothills areas.

Table 10 Distribution of farms in size category from 50 to 99.99 hectares in the Czech Republic in 2002 and 2010 according to natural conditions for agriculture

\begin{tabular}{|l|c|c|c|}
\hline \multicolumn{1}{|c|}{ price of agricultural land } & number of farms (2002) & number of farms (2010) & year 2002 =100 \\
\hline $\begin{array}{l}\leq 2.99 \mathrm{CZK} / \mathrm{m}^{2}(\leq 0.11 \text { Euro } / \\
\left.\mathrm{m}^{2}\right)\end{array}$ & 284 & 453 & 159.5 \\
\hline $\begin{array}{l}3-3.99 \mathrm{CZK} / \mathrm{m}^{2}(0.11-0.15 \text { Euro } \\
\left./ \mathrm{m}^{2}\right)\end{array}$ & 514 & 715 & 139.1 \\
\hline $\begin{array}{l}4-4.99 \mathrm{CZK} / \mathrm{m}^{2}(0.15-0.19 \text { Euro } \\
\left./ \mathrm{m}^{2}\right)\end{array}$ & 257 & 318 & 123.7 \\
\hline $\begin{array}{l}5-5.99 \mathrm{CZK} / \mathrm{m}^{2}(0.19-0.23 \text { Euro } \\
\left./ \mathrm{m}^{2}\right)\end{array}$ & 93 & 139 & 149.5 \\
\hline $\begin{array}{l}6-6.99 \mathrm{CZK} / \mathrm{m}^{2}(0.23-0.27 \text { Euro } \\
\left./ \mathrm{m}^{2}\right)\end{array}$ & 130 & 281 & 94.6 \\
\hline $\begin{array}{l}7-7.99 \mathrm{CZK} / \mathrm{m}^{2}(0.27-0.31 \text { Euro } \\
\left./ \mathrm{m}^{2}\right)\end{array}$ & 210 & 281 & 133.8 \\
\hline$\geq 8 \mathrm{CZK} / \mathrm{m}^{2}\left(\geq 0.31\right.$ Euro $\left./ \mathrm{m}^{2}\right)$ & 271 & 2,310 & 103.7 \\
\hline$\sum \mathrm{CZ} \mathrm{TOTAL}$ & 1,759 & & 131.3 \\
\hline
\end{tabular}

Source: Czech Statistical Office, own calculations.

${ }^{i}$ As administrative prices (not market prices) of agricultural lands are used for our calculations, natural conditions for agriculture can be simply ranked from the worst (the lowest prices) to the best (the highest prices). 
Table 11 Distribution of farms in size category from 50 to 99.99 hectares in the Czech Republic in 2002 and 2010 according to intensity of operation of agricultural AD plants

\begin{tabular}{|l|c|c|c|}
\hline \multicolumn{1}{|c|}{ groups } & number of farms (2002) & number offarms (2010) & year 2002 $=100$ \\
\hline B1 & 176 & 236 & 134.1 \\
\hline B2 & 234 & 337 & 144.0 \\
\hline$\sum$ B & 410 & 573 & 139.8 \\
\hline$\sum$ OTHER & 1,349 & 1,737 & 128.8 \\
\hline$\sum$ CZ TOTAL & 1,759 & 2,310 & 131.3 \\
\hline
\end{tabular}

Source: Czech Statistical Office, own calculations.

\section{Farms with 100 and more hectares of agricultural land}

The fourth size category are farms with more than hundred hectares of agricultural land. Even in this case, there is a clear increase in the share of this category in the monitored period to $9.4 \%$ of the total number of farms. It is obvious that most of this type of farms (12-13\%) are encountered in areas with slightly above average natural conditions (area with agricultural land price in the range 5-6.99 $\mathrm{CZK} / \mathrm{m}^{2}$ ), while relatively less are already found in the most fertile areas (7-8\%). From the analysis of the increase of the number of this type of farms in individual regions, the surface increase is about one-tenth (Tab. 13). It can be said that the distribution of this type of farms within the Czech Republic is the most balanced compared to other types. These farms manage a major part of the agricultural land of the Czech Republic and have a decisive influence on land management. No significant specificities were identified from the analysis of these farms in areas with the intensive operation of agricultural biogas stations (see Tab. 12).

Table 12 Distribution of farms in size category 100 and more hectares in the Czech Republic in 2002 and 2010

\begin{tabular}{|l|c|c|c|}
\hline \multicolumn{1}{|c|}{ groups } & number of farms (2002) & number of farms (2010) & year 2002 $=100$ \\
\hline B1 & 405 & 418 & 103.2 \\
\hline B2 & 433 & 482 & 111.3 \\
\hline$\sum$ B & 838 & 900 & 107.4 \\
\hline$\sum$ OTHER & 3,191 & 3,470 & 108.7 \\
\hline$\sum$ CZ TOTAL & 4,029 & 4,370 & 108.5 \\
\hline
\end{tabular}

Source: Czech Statistical Office, own calculations.

Table 13 Distribution of farms in size category 100 and more hectares in the Czech Republic in 2002 and 2010 according to natural conditions for agriculture

\begin{tabular}{|c|c|c|c|}
\hline price of agricultural land & $\begin{array}{c}\text { number of farms } \\
(2002)\end{array}$ & $\begin{array}{c}\text { number of farms } \\
(2010)\end{array}$ & year $2002=100$ \\
\hline$\leq 2.99 \mathrm{CZK} / \mathrm{m}^{2}\left(\leq 0.11\right.$ Euro $\left./ \mathrm{m}^{2}\right)$ & 708 & 766 & 108.2 \\
\hline $3-3.99 \mathrm{CZK} / \mathrm{m}^{2}\left(0.11-0.15\right.$ Euro $\left./ \mathrm{m}^{2}\right)$ & 1,150 & 1,287 & 111.9 \\
\hline $4-4.99 \mathrm{CZK} / \mathrm{m}^{2}\left(0.15-0.19\right.$ Euro $\left./ \mathrm{m}^{2}\right)$ & 496 & 548 & 110.5 \\
\hline $5-5.99 \mathrm{CZK} / \mathrm{m}^{2}\left(0.19-.023\right.$ Euro $\left./ \mathrm{m}^{2}\right)$ & 274 & 284 & 103.6 \\
\hline $6-6.99 \mathrm{CZK} / \mathrm{m}^{2}\left(0.23-0.27\right.$ Euro $\left./ \mathrm{m}^{2}\right)$ & 280 & 297 & 106.1 \\
\hline $7-7.99 \mathrm{CZK} / \mathrm{m}^{2}\left(0.27-0.31\right.$ Euro $\left./ \mathrm{m}^{2}\right)$ & 458 & 516 & 101.4 \\
\hline$\geq 8 \mathrm{CZK} / \mathrm{m}^{2}\left(\geq 0.31\right.$ Euro $\left./ \mathrm{m}^{2}\right)$ & 663 & 672 & 108.5 \\
\hline$\sum \mathrm{CZ} \mathrm{TOTAL}$ & 4,029 & 4,370 & \\
\hline
\end{tabular}

Source: Czech Statistical Office, own calculations.

${ }^{\mathrm{i}}$ As administrative prices (not market prices) of agricultural lands are used for our calculations, natural conditions for agriculture can be simply ranked from the worst (the lowest prices) to the best (the highest prices). 
As mentioned above, farms with an area of 100 hectares or more of agricultural land are the decisive driving force of Czech agriculture. Given the enormous scope of this category, which includes larger corporations of natural persons and smaller limited liability companies slightly larger than the hundred-hectare exchange, as well as huge thousands of hectares, we have added a time horizon of 2006 for which is the internal structure of these largest of agricultural holdings available (unfortunately only available for 2002 for enterprises with more than 100 hectares as total). Therefore, for the 2006-2010 period, enterprises with a size of 100-499.99 hectares and then enterprises with 500 hectares and more were first evaluated. First, we say a few words about farms with an area of 100-499.99 hectares.

In terms of numbers, farms with an area of 100-499.99 hectares account for $5.5 \%$ of the total number of farms in the Czech Republic (2,579 in 2010). The number of these farms grew by about $9 \%$ in the monitored period (207 new businesses were added to the category). The distribution of these farms does not show significant differences depending on the natural conditions. It is only possible to state a higher level of these farms in above-average farming conditions (5-6.99 $\mathrm{CZK} / \mathrm{m}^{2}$ ), where the share of these farms reaches more than $7 \%$, while in the most fertile areas it is less than $5 \%$ (see Tab. 14).

Table 14 Distribution of farms in size category from 100 to 499.99 hectares in the Czech Republic in 2006 and 2010 according to natural conditions for agriculture

\begin{tabular}{|l|c|c|c|}
\hline \multicolumn{1}{|c|}{ price of agricultural land } & $\begin{array}{c}\text { number of farms } \\
(2002)\end{array}$ & $\begin{array}{c}\text { number of farms } \\
(2010)\end{array}$ & year 2002 \\
\hline$\leq 2.99 \mathrm{CZK} / \mathrm{m}^{2}\left(\leq 0.11\right.$ Euro $\left./ \mathrm{m}^{2}\right)$ & 423 & 455 & 107.6 \\
\hline $3-3.99 \mathrm{CZK} / \mathrm{m}^{2}\left(0.11-0.15 \mathrm{Euro} / \mathrm{m}^{2}\right)$ & 667 & 739 & 110.8 \\
\hline $4-4.99 \mathrm{CZK} / \mathrm{m}^{2}\left(0.15-0.19\right.$ Euro $\left./ \mathrm{m}^{2}\right)$ & 299 & 328 & 109.7 \\
\hline $5-5.99 \mathrm{CZK} / \mathrm{m}^{2}\left(0.19-.023\right.$ Euro $\left./ \mathrm{m}^{2}\right)$ & 163 & 176 & 108.0 \\
\hline $6-6.99 \mathrm{CZK} / \mathrm{m}^{2}\left(0.23-0.27\right.$ Euro $\left./ \mathrm{m}^{2}\right)$ & 165 & 187 & 113.3 \\
\hline $7-7.99 \mathrm{CZK} / \mathrm{m}^{2}\left(0.27-0.31\right.$ Euro $\left./ \mathrm{m}^{2}\right)$ & 309 & 320 & 103.6 \\
\hline$\geq 8 \mathrm{CZK} / \mathrm{m}^{2}\left(\geq 0.31\right.$ Euro $\left./ \mathrm{m}^{2}\right)$ & 346 & 374 & 108.7 \\
\hline$\sum \mathrm{CZ} \mathrm{TOTAL}$ & 2,372 & 2,579 & \\
\hline
\end{tabular}

Source: Czech Statistical Office, own calculations.

${ }^{\mathrm{i}}$ As administrative prices (not market prices) of agricultural lands are used for our calculations, natural conditions for agriculture can be simply ranked from the worst (the lowest prices) to the best (the highest prices).

Looking at farms with an area of 100-499.99 hectares of high-intensity areas of agricultural biogas stations (Tab. 15), we do not find any significant differences. Only for the area, B2 was a higher rate of increase in the number of these farms observed (17\%) over time, which exceeds the increase in the other categories of areas. It can be stated, therefore, that the number of large farms is growing strongly in the area B2 that is in an area with an increased intensity of operation of biogas stations.

The last evaluated size category of farms are businesses with an area of 500 hectares of agricultural land and more. This largest type of farms is found in the Czech Republic in 1,791 cases and represents a 3.9\% share of the total number of farms, which did not change much in the monitored period of 2006-2010. However, the number of these farms has been progressively reduced (by 38 units since 2006), indicating a gradual decline in the importance of the largest farms, which have no significant features in their deployment in the context of changing natural conditions (see Tab. 16). 
Table 15 Distribution of farms in size category from 100 to 499.99 hectares in the Czech Republic in 2002 and 2010 according to intensity of operation of agricultural AD plants

\begin{tabular}{|l|c|c|c|}
\hline \multicolumn{1}{|c|}{ groups } & number of farms (2002) & number of farms (2010) & year 2002 $=100$ \\
\hline B1 & 202 & 223 & 110.4 \\
\hline B2 & 231 & 271 & 117.3 \\
\hline$\sum$ B & 433 & 494 & 114.1 \\
\hline$\sum$ OTHER & 1,939 & 2,085 & 107.5 \\
\hline$\sum$ CZ TOTAL & 2,372 & 2,579 & 108.7 \\
\hline
\end{tabular}

Source: Czech Statistical Office, own calculations.

Table 16 Distribution of farms in size category 500 and more hectares in the Czech Republic in 2006 and 2010 according to natural conditions for agriculture

\begin{tabular}{|l|c|c|c|}
\hline price of agricultural land & $\begin{array}{c}\text { number of farms } \\
(2006)\end{array}$ & $\begin{array}{c}\text { number of farms } \\
(2010)\end{array}$ & year 2002 $=100$ \\
\hline$\leq 2.99 \mathrm{CZK} / \mathrm{m}^{2}\left(\leq 0.11\right.$ Euro $\left./ \mathrm{m}^{2}\right)$ & 311 & 311 & 100.0 \\
\hline $3-3.99 \mathrm{CZK} / \mathrm{m}^{2}\left(0.11-0.15 \mathrm{Euro} / \mathrm{m}^{2}\right)$ & 559 & 548 & 98.0 \\
\hline $4-4.99 \mathrm{CZK} / \mathrm{m}^{2}\left(0.15-0.19\right.$ Euro $\left./ \mathrm{m}^{2}\right)$ & 226 & 220 & 97.3 \\
\hline $5-5.99 \mathrm{CZK} / \mathrm{m}^{2}\left(0.19-.023\right.$ Euro $\left./ \mathrm{m}^{2}\right)$ & 119 & 108 & 90.8 \\
\hline $6-6.99 \mathrm{CZK} / \mathrm{m}^{2}\left(0.23-0.27\right.$ Euro $\left./ \mathrm{m}^{2}\right)$ & 113 & 110 & 97.3 \\
\hline $7-7.99 \mathrm{CZK} / \mathrm{m}^{2}\left(0.27-0.31\right.$ Euro $\left./ \mathrm{m}^{2}\right)$ & 192 & 196 & 96.4 \\
\hline$\geq 8 \mathrm{CZK} / \mathrm{m}^{2}\left(\geq 0.31\right.$ Euro $\left./ \mathrm{m}^{2}\right)$ & 309 & 298 & 97.9 \\
\hline$\sum \mathrm{CZ} \mathrm{TOTAL}$ & 1,829 & 1,791 & \\
\hline
\end{tabular}

Source: Czech Statistical Office, own calculations.

i As administrative prices (not market prices) of agricultural lands are used for our calculations, natural conditions for agriculture can be simply ranked from the worst (the lowest prices) to the best (the highest prices).

However, in the case of areas with the intensive operation of agricultural biogas stations, we find certain specificities in relation to these largest farms (Tab. 17). The occurrence of this category of farms is relatively higher here (in category B1 to 5\%), however, given the occurrence of these increased shares in the two monitored periods, this fact cannot be related to the operation of biogas stations. From the point of view of the changing number of these types of enterprises, the relatively higher stability of their number is typical. This type of farms is usually the most flexible as for their capital to be invested or to get a bank loan for reasonable interests which makes their operation specific.

Table 17 Distribution of farms in size category 500 and more hectares in the Czech Republic in 2002 and 2010 according to intensity of operation of agricultural AD plants

\begin{tabular}{|l|c|c|c|}
\hline $\begin{array}{c}\text { price of agricultural } \\
\text { land }\end{array}$ & $\begin{array}{c}\text { number of farms (2002) } \\
\text { number of farms (2010) }\end{array}$ & year 2002 $=100$ \\
\hline B1 & 200 & 195 & 97.5 \\
\hline B2 & 212 & 211 & 99.5 \\
\hline$\sum$ B & 412 & 406 & 98.5 \\
\hline$\sum$ OTHER & 1,417 & 1,385 & 97.7 \\
\hline$\sum$ CZ TOTAL & 1,829 & 1,791 & 97.9 \\
\hline
\end{tabular}

Source: Czech Statistical Office, own calculations. 


\section{DISCUSSION AND CONCLUSION}

This paper has examined how the size of agricultural farms in the Czech Republic varies according to changing natural conditions and what the distribution of $\mathrm{AD}$ plants can tell us about the strategies of certain farm types. We found that agricultural AD plants have a tendency to concentrate in areas with larger agricultural farms and also in areas with average and slightly below average natural conditions for agricultural activities. We can say that this has been heavily affected by the massive support policy of the Czech Government and the EU for development of AD plants in the Czech Republic after 2004. This policy followed an idea of development of $\mathrm{AD}$ plants as a tool that helps farmers in times when their traditional agricultural activities were declining due to competition with large scale imports of cheaper food from abroad. Thus, environmental concerns and concerns about benefits for local development were not taken into account. As a result of this policy, it was mainly big farms in the Czech Republic who set up AD plants. As co-funding from own sources was necessary, smaller farms (who have more limited access to bank loans) were largely excluded from this opportunity. Moreover, our research results show that large farms tend to crowd out smaller farms out of areas with dense occurrence of $\mathrm{AD}$ plants where pressure to grow maize for ADs significantly competes with growing of other agricultural crops. This finding is in strong contradiction with the official national agricultural policy where support for small farms is systematically emphasized.

The location of the majority of $\mathrm{AD}$ plants in areas with average and below-average natural conditions for farming can be explained as the effect of operators' decisions who tend to focus their agricultural activities (food production) on land of the best quality whilst diversify their economy by changing the activities on land with less favourable natural conditions. For comparative purposes it is worth noting that the average size of agricultural farm in the Czech Republic dramatically exceeds the size of farms in Western Europe which could make the Czech farms more profitable.

Our paper illustrates discrepancies in the different objectives of the Common Agricultural Policy of the European Union and national support of the Czech Republic, which primarily targeted their subsidy schemes to support the development of agricultural AD plants on the largest agricultural farms, while in the European context support was more targeted to typical western farms that are much smaller (Chaplin et al., 2004, Breustedt and Glauben, 2007, Bojnec and Latruffe, 2013). As a result of this support, the areas where agricultural AD plants are primarily concentrated within the Czech Republic are the Cesko-moravska vrchovina Highlands, the adjacent part of southern Bohemia and the area under the Orlicke hory Mountains. These areas have seen significant changes in agricultural outputs due to increasing local demand for intentionally grown crops for AD plants (especially for green maize), taking 
the place of other crops (especially potatoes) that were no longer profitable since the country entered the EU and opened its borders to cheaper food imports. The usage of agricultural waste in these $\mathrm{AD}$ plants is very low, which together with the under-utilisation of heat outputs, strongly limits the potential environmental benefits of operating these agricultural AD plants.

\section{LIMITATIONS OF THE STUDY}

The authors acknowledge that the data analysed in the research are not that recent; spatiotemporal changes and consequences of the size structure of agricultural farm and spatial distribution of AD plant have been analysed for 2002 and 2010. The building of new AD plants in the Czech Republic has been stopped in 2014 when supports for new AD plants was ended, so our results do not cover the whole period of diffusion of AD plants in the Czech Republic. However, we believe that our results might contribute to the detection of factors that lie behind the current distribution of AD plants in the Czech Republic. We are also aware that our study is based only on selected indicators as the administrative price of agricultural land and size of agricultural farms and it would be beneficial if some other indicators were also studied and more sophisticated statistical tools employed. We endeavour to develop this topic in future papers.

\section{Acknowledgement}

The research was kindly supported by the Grant Agency of the Czech Republic (the project with title Socio-spatial diffusion of renewable energy projects in the Czech Republic, No. 16-04483S) and by the COST Action 1401 Renewable Energy and Landscape Quality (RELY), which is kindly supported by the Horizon2020 programme.

\section{REFERENCES}

Agrocenzus. (2010). Strukturální setření v zemědělství a metody zemědělské výroby [Structural survey in agriculture and methods of agricultural production]. Regiony. Praha: Český statistický úřad, 2010.

Bojnec, Š., \& Latruffe, L. (2013). Farm size, agricultural subsidies and farm performance in Slovenia. Land Use Policy, 32, 207-217.

Braun, R. (2007). Anaerobic digestion: a multi-faceted process for energy, environmental management and rural development. Improvement of crop plants for industrial end uses. Ranalli, P. (ed.). Netherlands: Springer, 2007, 335-416.

Breustedt, G., \& Glauben, T. (2007). Driving forces behind exiting from farming in Western Europe. Journal of Agricultural Economics, 58(1), 115-127.

Bridge, G., Bouzarovski, S., Bradshaw, M., \& Eyre, N. (2013). Geographies of energy transition: Space, place and the low-carbon economy. Energy Policy, 53, 331-340.

Budzianowski, W. M. (2012). Sustainable biogas energy in Poland: Prospects and challenges. Renewable and Sustainable Energy Reviews, 16(1), 342-349.

Centeri, C., Szalai, Z., Jakab, G. I., Barta, K., Farsang, A., Szabó, S., \& Biró, Z. (2015). Soil erodibility calculations based on different particle size distribution measurements. Hungarian Geographical Bulletin, 64(1), 17-23.

Darnhofer, I. (2005). Organic farming and rural development: Some evidence from Austria. In Sociologia Ruralis, 45(4), 308-323. 
de Roest, K., Ferrari, P., \& Knickel, K. (2017). Specialisation and economies of scale or diversification and economies of scope? Assessing different agricultural development pathways. Journal of Rural Studies. In press, available online 15 July, 2017, doi: org/10.1016/j.jrurstud.2017.04.013

Dóci, G., \& Gotchev, B. (2016). When energy policy meets community: rethinking risk perceptions of renewable energy in Germany and the Netherlands. Energy Research \& Social Science, 22, 26-35.

Doležalová, H., Pícha, K., Navrátil, J., \& Bezemková, A. (2014a). Changes in the structure of the regional agricultural production (South Bohemian region). Journal of Central European Agriculture, 15(3), 335-353.

Doležalová, H., Pícha, K., Navrátil, J., Bezemková, A. (2014b). Factors that influence the selling of milk through milk vending machines. Acta Universitatis Agriculturae et Silviculturae Mendelianae Brunensis, 62(4), 641-650.

Doležalová, H., Pícha, K., \& Navrátil, J. (2009). Analysis of the organic food marketingchain store companies (South Bohemia). Agricultural Economics-Czech, 55(9), 446458.

Duffy, M. (2009). Economies of size in production agriculture. Journal of hunger \& environmental nutrition, 4(3-4), 375-392.

Duží, B., Frantál, B., \& Rojo, M. S. (2017). The geography of urban agriculture: New trends and challenges. Moravian Geographical Reports, 25(3), 130-138.

Fernandez-Cornejo, J., Gempesaw, C. M., Elterich, J. G., \& Stefanou, S. E. (1992). Dynamic measures of scope and scale economies: an application to German agriculture. American Journal of Agricultural Economics, 74(2), 329-342.

Frantál, B., Malý, J., Ouředníček, M., \& Nemeškal, J. (2016). Distance matters. Assessing socioeconomic impacts of the Dukovany nuclear power plant in the Czech Republic: Local perceptions and statistical evidence. Moravian Geographical Reports, 24(1), 2-13.

Frantál, B., \& Prousek, A. (2016). It's not right, but we do it. Exploring why and how Czech farmers become renewable energy producers. Biomass and Bioenergy, 55, 26-34.

Frantál, B., Pasqualetti, M. J., \& Van der Horst, D. (2014). New trends and challenges for energy geographies: Introduction to the special issue. Moravian Geographical Reports, 22(2), 2-6.

Gorton, M., \& Davidova, S. (2004). Farm productivity and efficiency in the CEE applicant countries: a synthesis of results. Agricultural Economics, 30(1), 1-16.

Chaplin, H., Davidova, S., \& Gorton, M. (2004). Agricultural adjustment and the diversification of farm households and corporate farms in Central Europe. Journal of Rural Studies, 20(1), 61-77.

Chodkowska-Miszczuk, J., \& Szymańska, D. (2013). Agricultural biogas plants-A chance for diversification of agriculture in Poland. Renewable and Sustainable Energy Reviews, 20, 514-518.

Chodkowska-Miszczuk, J., Kulla, M., \& Novotný, L. (2017). The role of energy policy in agricultural biogas energy production in Visegrad countries. Bulletin of Geography. Socio-economic Series, 35(35), 19-34.

Klagge, B., \& Brocke, T. (2012). Decentralized electricity generation from renewable sources as a chance for local economic development: a qualitative study of two pioneer regions in Germany. Energy, Sustainability and Society, 2(1), 5.

Krugman, P. (1980). Scale economies, product differentiation, and the pattern of trade. The American Economic Review, 70(5), 950-959.

Silva, L., \& Delicado, A. (2017). Wind farms and rural tourism: A Portuguese case study of residents' and visitors' perceptions and attitudes. Moravian Geographical Reports, 25(4), 248-256.

Marcato, C. E., Mohtar, R., Revel, J. C., Pouech, P., Hafidi, M., \& Guiresse, M. (2009). Impact of anaerobic digestion on organic matter quality in pig slurry. International Biodeterioration \& Biodegradation, 63(3), 260-266.

Martinát, S., Mintálová, T., Dvořák, P., Navrátil, J., Klusáček, P., \& Kunc, J. (2013). Does rural space benefit from location of anaerobic digestion plants? Perspective of municipal administration. Geographia Cassoviensis, 7(2), 41-49. 
Martinát, S., Dvořák, P., Frantál, B., Klusáček, P., Kunc, J., Kulla, M., Mintálová, T., Navrátil, J., \& Van der Horst, D. (2013). Spatial consequences of biogas production and agricultural changes in the Czech Republic after EU accession: mutual symbiosis, coexistence or parasitism? Acta Universitatis Palackianae Olomucensis-Geographica, 44(2), 75-92.

Martinát, S., Navrátil, J., Dvořák, P., Van der Horst, D., Klusáček, P., Kunc, J., \& Frantál, B. (2016). Where AD plants wildly grow: The spatio-temporal diffusion of agricultural biogas production in the Czech Republic. Renewable Energy, 95, 85-97.

Martinát, S., \& Turečková, K. (2016). Local development in the post-mining countryside? Impacts of an agricultural AD plant on rural developlopment. Geographia Technica, $11(1), 54-66$.

(Mze). 2002. Vyhláška č. 463/2002 Sb., kterou se stanoví seznam katastrálních území s přiřazenými průměrnými základními cenami zemědělských pozemků [the Decree No. 463/2002 Coll. on average prices of agricultural lands). Praha: Ministerstvo zemědělství.

Národní akční plán České republiky pro rozvoj obnovitelných zdrojů (2010). [National Action Plan of the Czech Republic for Development of Renewable Energy]. Praha: Ministerstvo průmyslu a obchodu, 2010.

Navrátil, J., Knotek, J., Pícha, K., \& Fialová, J. (2015). The protected areas: are they still in the "pleasure periphery" or they are destinations for sustainable tourism activities. European Journal of Tourism Research, 11, 57-72.

Pan, S. Y., Du, M. A., Huang, I. T., Liu, I. H., Chang, E. E., \& Chiang, P. C. (2015). Strategies on implementation of waste-to-energy (WTE) supply chain for circular economy system: a review. Journal of Cleaner Production, 108, 409-421.

Park, C. M., \& Novak, J. T. (2013). The effect of direct addition of iron (III) on anaerobic digestion efficiency and odor causing compounds. Water Science and Technology, 68(11), 2391-2396.

Paul, S., Dutta, A., Defersha, F., \& Dubey, B. (2017). Municipal Food Waste to Biomethane and Biofertilizer: A Circular Economy Concept. Waste and Biomass Valorization, 1-11. doi: 10.1007/s12649-017-0014-y

Paul, C., Nehring, R., Banker, D., \& Somwaru, A. (2004). Scale economies and efficiency in US agriculture: are traditional farms history? Journal of Productivity Analysis, 22(3), 185-205.

Pantaleo, A., De Gennaro, B., \& Shah, N. (2013). Assessment of optimal size of anaerobic codigestion plants: an application to cattle farms in the province of Bari (Italy). Renewable and Sustainable Energy Reviews, 20, 57-70.

Plieninger, T., Bens, O., \& Hüttl, R. F. (2006). Perspectives of bioenergy for agriculture and rural areas. Outlook on Agriculture, 35(2), 123-127.

Skovsgaard, L., \& Jacobsen, H. K. (2017). Economies of scale in biogas production and the significance of flexible regulation. Energy Policy, 101, 77-89.

Soland, M., Steimer, N., \& Walter, G. (2013). Local acceptance of existing biogas plants in Switzerland. Energy Policy, 61, 802-810

Styles, D., Dominguez, E. M., \& Chadwick, D. (2016). Environmental balance of the UK biogas sector: An evaluation by consequential life cycle assessment. Science of the Total Environment, 560, 241-253.

Szymańska, D., \& Chodkowska-Miszczuk, J. (2011). Endogenous resources utilization of rural areas in shaping sustainable development in Poland. Renewable and Sustainable Energy Reviews, 15(3), 1497-1501.

Upreti, B. R., \& van der Horst, D. (2004). National renewable energy policy and local opposition in the UK: the failed development of a biomass electricity plant. Biomass and Bioenergy, 26(1), 61-69.

Van der Horst, D. 2014. Landscapes of lost energy: Counterfactual geographical imaginary for a more sustainable society. Moravian Geographical Reports, 22(2), 66-72.

Zoellner, J., Schweizer-Ries, P., \& Wemheuer, C. (2008). Public acceptance of renewable energies: Results from case studies in Germany. Energy policy, 36(11), 4136-4141.

Ženka, J., Slach, O., Krtička, L., \& Žufan, P. (2016). Determinants of microregional agricultural labour productivity-Evidence from Czechia. Applied Geography, 71, 83-94. 